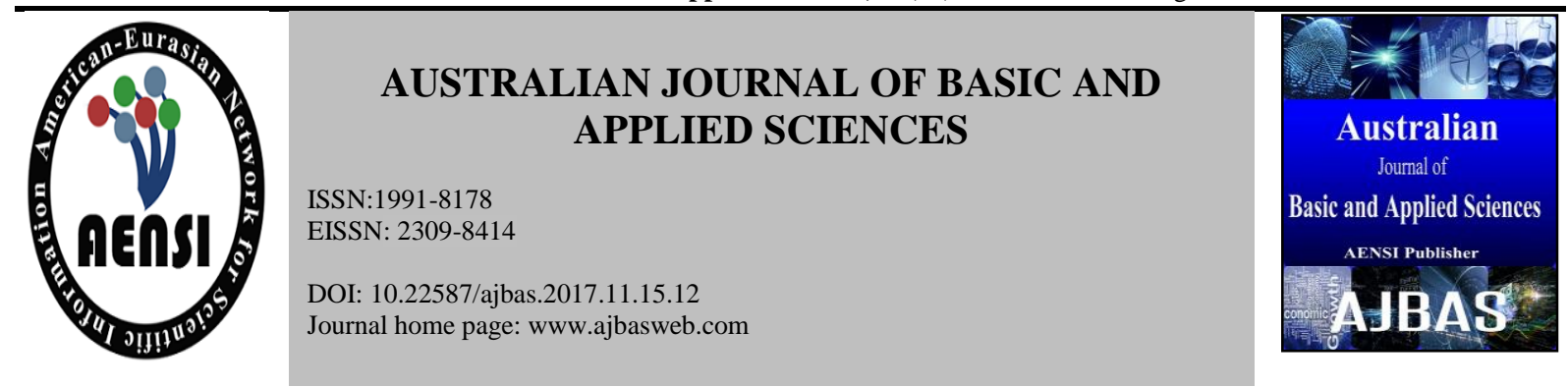

\title{
Constructing Model to Explore the Influence of Marketing Audit on Organizational Performance
}

\author{
${ }^{1}$ Mohammed Abdulellah Yousuf Saeed, ${ }^{2}$ Hussain Ali Bekhet, ${ }^{3}$ Bablu Kumar Dhar \\ ${ }^{2}$ Professor Dr. Hussain Ali Bekhet, Department of Graduate Business School, Universiti Tenaga Nasional, Malaysia \\ ${ }^{3}$ Bablu Kumar Dhar, Doctoral Candidate, Faculty of Leadership and Management, Universiti Sains Islam Malaysia, Malaysia
}

Address For Correspondence:

Mohammed Abdulellah Yousuf Saeed, Doctoral Candidate, Department of Graduate Business School, Universiti Tenaga Nasional, Malaysia.

E-mail: moham_faras78@hotmail.com

\section{ARTICLE INFO}

Article history:

Received 12 October 2017

Accepted 22 December 2017

Available online 31 December 2017

Keywords:

Marketing Audit

Dimension of Marketing Audit

Organizational Performance

\begin{abstract}
A B S T R A C T
Background: The study is based on conceptual research. Through this study, a model is proposed to find out the relationship among marketing environmental audit, strategy audit, organizational audit, system audit, productivity audit and function audit and organizational performance. The study adopted the dimension of marketing audit as independent variables, and Performance as a dependent variable. Objective: The purpose of this paper is to develop a model to explore the impact of marketing audit on performance organizations. Results: Based on the developed model, it can be continued to find out the impact of marketing audit on performance of different types of business. Conclusion: Applying this empirical study, organizations may generate new policies and strategies for improving performance in different industries of different countries.
\end{abstract}

\section{INTRODUCTION}

Marketing is the action and processes of creating ideas, communicating people, delivering services, and exchanging offers that have value for customers, partners, clients and society (American Marketing Association, 2013). Marketing increases pressure to grow and utensil business-oriented approaches and evaluates to enhance not just marketing only, but complete efficiency of business also (Al Fahad et al., 2015).

Market-oriented corporate culture progressively considered as a vital component of superior organizational performance (Han et al., 1998; Lai and Cheng, 2005; Ullah and Ahmed, 2017). All profitable organizations are using a good portion of their budget for marketing purpose. After end of financial or fiscal year, organizations audit their financial transactions for proper justification where marketing lies out of focus. Therefore, justifying marketing related plans, objectives, strategies and activities become necessary (Loya, 2011). Marketing researchers have scrutinized for strategies over the past few decades to support improved understanding of mix of environmental factors that possibly boosts organizational performance. For this purpose, several models and theories, including market orientation models, have been established and verified throughout last few decades (Diamantopoulos and Hart, 1993; Narver and Slater, 1990; Pelham, 2000; Taghian and Shaw, 2008).

Through marketing, the level of customer expands. However, through marketing audit, the performance of an organization can be justified. Recently, people perceive more about the marketing audit as it is being used to estimate marketing practices alike public accounting audit. It is a new initiative and an enormously diverse methodology. It is a generally acknowledged technique of assessment and a control instrument of marketing performance. That is the reason why the study focuses on the relationship between marketing audit and organizational performance.

The purpose of this conceptual research is to construct a model to explore the influence of marketing audit on organizational performance. The remaining sections of this research are designed as follows: Section 2

Open Access Journal

Published BY AENSI Publication

(C) 2017 AENSI Publisher All rights reserved

This work is licensed under the Creative Commons Attribution International License (CC BY). http://creativecommons.org/licenses/by/4.0/

\section{Open Access}

To Cite This Article: Mohammed Abdulellah Yousuf Saeed, Hussain Ali Bekhet, Bablu Kumar Dhar, Constructing Model to Explore the Influence of Marketing Audit on Organizational Performance. Aust. J. Basic \& Appl. Sci., 11(15):83-90, 2017 
defines the relevant literature and analysis of gap; Section 3 focuses on methodology including propose research model, research instruments and process of data analysis and Section 4 presents conclusion which includes future research directions.

\section{Literature Review: \\ Marketing Audit and Organizational Performance:}

Marketing audit started to recognize from Kotler (1967). Kotler devoted a chapter regarding marketing audit in his book. Ten years later (Kotler et al., 1977), it has become a turning point while there was a publication named "The Marketing Audit comes of Age". Precisely, that research provided definition, development process and possible problems of marketing audit has become a basement of reference for numerous researchers who contributed to supplementary expansion of the marketing audit (Brownlie, 1996a). According to Taghian and Shaw (1998), marketing audit is usually recognized technique of estimation and a regulating mechanism of marketing performance. Moreover, their research suggested a model for an extended role of marketing audit.

There are several researches that indicated on the process of marketing audit (Achua and Alabar, 2014; Bonoma and Bruce, 1998; Broberg et al., 2013; Brownlie, 1996 a, b; Brownlie; 1993; Capella and Sekely, 1978; Clark et al., 2006; Jha, 2013; Kotler \& Turner, 1979; Kotler et al., 1977; Kotler et al., 1980; Kotler, 1967, 1988; Kotler, 1997; McDonald et al., 1991; Morgan et al. 2002; Radulescu and Cetina, 2012; Rothe et al., 1997; Solod, 1996; Sutcliffe, 1975; Wilson, 1982, 1993; Wu et al., 2015). Different researchers worked on different perspective of marketing audit. Brownlie (1996a, b; 1993); Brownlie and Bruce (1988); Kolter et al., (1980, 1977, 1979); Kotler (1997, 1967, 1988); Lipnická and Dado (2013); Odote and Robby (2013); Rothe et al., (1997); Solod (1996) and Sutcliffe (1975) focused on concept of marketing audit and tried to develop the concept in different time from different angle of view.

According to their research, marketing audit can be conducted in various ways, for example, audit from above, audit from across, self-audit, company task force audit, company auditing office and external audit. As a tool of measurement, marketing audit measures risk, value and effectiveness of marketing efforts of an organization (Radulescu and Cetina, 2012). According to the research, starting point of the marketing audit is the market. The importance of building strategic relationships between organization and customer for effective marketing is the auditing of market. This audit can be done internally as well as externally (Achua and Alabar, 2014). Broberg et al., (2013) explored auditors' attitudes toward marketing. Bonoma et al., (1988), Clark et al., (2006) focused on marketing performance assessment. On the contrary, Wilson (1982, 1993) worked for developing marketing audit checklist. Capella and Sekely (1978) tried to develop methods, problems and perspectives of marketing audit. McDonald et al., (1991) and Wu et al., (2015) worked on the practice and application of marketing audit in business. The research of Wu et al., (2015) shows that marketing audit can contribute significantly to marketing performance, and marketing audit mediates association between environmental factors and marketing performance. Akroush and Al-Mohammad (2010); Chin et al., (2013); Han et al., (1998); Mohammadzadeh et al., (2013); Saif (2015); Taghian and Shaw (2008) indicated a relationship among market strategy, market orientation and organizational performance. Alipour et al., (2011) worked on impact of marketing mix on performance and marketing audit. Day and Nedungadi (1994), Day and Fahey (1988); Kaplan and Norton (1993), Morgan et al., (2002) focused on marketing productivity and marketing systems for assessing marketing performance.

The goal of an organization is to maximize wealth for stake-holders and to provide benefit to the stockholders (Absar et al., 2010; Becker \& Fuseli, 1998; Horngren et al., 2000). According to the research of Bontis (1998), Cheng et al. (2010), Dhar et al., 2017a, b; Karimi, (2014), Khalique et al. (2011), and Sharabati et al. (2010) profitability, productivity and valuation of market are three major indicators of business performance. Output can be justified in two ways; based on actual goods and services produced and by considering people relative to key financial performance. Profitability arises when revenue exceeds over the costs. It is can be measured using sales and profit growth. Sales growth indicates the increase in sales for a definite period and profit growth is a combination of profitability and growth (Karimi, 2014). Market valuation indicates when market value exceeds its book value. Market valuation is the ratio of the total market capitalization which is the average share price time's number of outstanding common shares to book value of net assets (Karimi, 2014). Based on discussion, following hypothesis arises:

H1: Marketing audit influences organizational performance

\section{Dimension of Marketing Audit:}

Marketing audit begins with market place and explores changes that are happening in marketplace. It examines organization's marketing objectives and strategies and systems. Moreover, it inspects marketing functions in more detail and scrutinize important marketing performance of the company. Marketing audit follows following sectors as components of marketing audit: 


\section{Marketing Environmental Audit:}

Amstrong (1977); Dess (1984); Kotler et al. (1977); Loya (2011); Mylonakis, (2003); Odote and Robby (2013) and Shuchman, (1959) analyzed task environmental and macro-environment forces and trends. Marketing environment audit considers two types of environments, environment audit and macro-environmental audit.

Task environment audit estimates Markets-market growth, size, geographical market segments and distribution, customers' needs and buying processes. Moreover, it emphases on product quality, service, sales force and price, competitors, distribution \& dealers, suppliers, facilitators \& marketing firms and publics.

Macro-environmental component scrutinizes different extents, for example, Economical factorsdevelopments in income, prices, savings and credit will affect the company, Demographics-key demographic developments and trends pose opportunities, Technological factors - transformation occurring in product and process technology and company's position in these technologies, Cultural - community's attitude towards business and toward the company's products and changes in customer lifestyles and values might affect an organization. Political factors - modifications in laws and regulations might affect marketing strategy and tactics and the changes in the areas of product safety, pollution control, equal employment opportunity, price control, advertising which affects the marketing strategy of an organization.

If there is proper evaluation of marketing environmental audit, organizational performance will be affected too. Thus, the following hypothesis arises:

H2: Marketing environment audit influences organizational performance

\section{Marketing Strategy Audit:}

Amstrong et al., (1977); Baum et al.,(2003); Beaver, (1989); Brownlie, (1996b); Egeren and O'Connor (1998); Hasty and Reardon (1997); Jennings and Beaver (1997); Khandwalla, (1977); Kottler, (1977); Loya (2011); Rudman (1998); Sauter (1999); Wallace, (1980); Zahra, (1996) and Zahra, (1996) mentioned about marketing strategy audit which reviews the organization's marketing purposes and marketing strategy to evaluate how well these are modified to existing and predicted marketing environment. Marketing strategy audit is vigorous for organization, and it makes sure that an organization's marketing strategy is appropriate with organization's marketing goals as well as organizational goals which may influence organizational performance. Based on that the following hypothesis occurs:

H3: Marketing strategy audit influences organizational performance

\section{Marketing Organizational Audit:}

Allaire and Firsirotu (1990); Drenth et al., (1998); Loya (2011); Mugenda and Mugenda (2003); Myers and Myers, (1982) and Trice and Beyer (1984) emphasized on marketing organization audit which evaluates the capabilities of the marketing organization for implementing the necessary strategy for the forecasted environment. Marketing organization audit is mostly measured effectiveness of an organization activities and efficiency of operation of an organization. Activities and management functions are considered such as research and development, manufacturing, financing, purchasing which may influence organizational performance. Hence, the following hypothesis needs to justify:

H4: Marketing organization audit influences organizational performance

\section{Marketing System Audit:}

Al-Fahad et al., (2015) introduced marketing system audit which assesses quality of an organizational systems for analysis, planning and control. Marketing auditor considers whether an organizational uses suitable marketing system for collecting information, plan the activities, control the operations and to continue smoothly regular operations. Most of organizations use different type of marketing systems, such as marketing planning systems, marketing information systems, new product development systems and marketing control systems, to gather information and control operation which influences the performance. Thus, the following hypothesis rises:

\section{H5: Marketing system audit influences organizational performance}

\section{Marketing Productivity Audit:}

Al-Fahad et al., 2015); Katsikeas et al., (2016); Loya (2011) and Sheth and Sisodia, 2002 pointed out marketing productivity audit that examines profitability of diverse marketing and cost effectiveness of diverse marketing expenditures. Most of the organizations are functioning to earn more profits. Marketing productivity audit is focused on evaluating organizational profits and revenue. That is why, marketing productivity audit plays significant role to evaluate marketing performance as well as business performance. Based on above, the following hypothesis is formulated:

H6: Marketing productivity audit influences organizational performance 


\section{Marketing Functions Audit:}

Arrow (1985); Egeren, (1998) and Loya (2011) introduced marketing functions audit which make evaluate marketing mix components namely products price, distribution, sales-force, advertising, promotion and publicity. Under marketing function audit, auditor uses marketing mix elements to investigate organization's functions such as product, place, price and promotion that influences business performance. Therefore, the following hypothesis may be tested:

H7: Marketing functions audit influences organizational performance

Based on the previous literature, it is clear that there is a scope to research to find out the influence of marketing audit on organizational performance.

\section{Methodology:}

\section{Proposed Framework:}

Based on literature, there is a scope of research to construct a model to explore the influence of marketing audit on organizational performance. The following Fig. 1 indicates the research model based on the gap of literature:

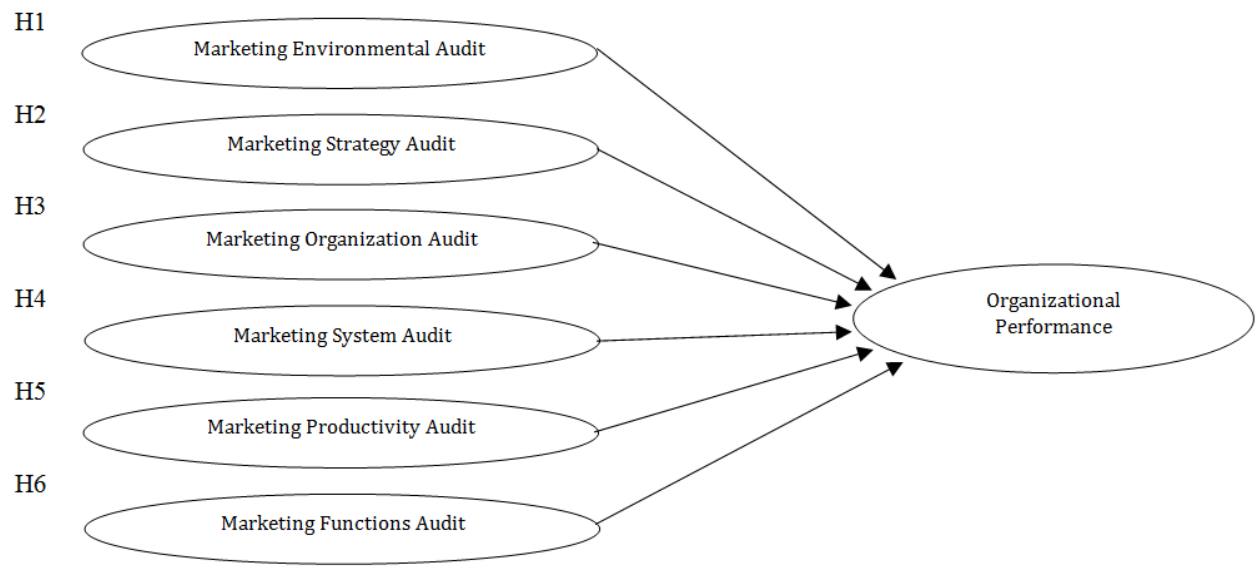

Fig. 1: Conceptual Research Framework

\section{Research Instruments:}

\section{Marketing Environmental Audit:}

Marketing environmental audit depends on Macro-environmental and Task-environmental. Macroenvironmental depends on Demographics, Economic, Environmental, Technology, Political and Cultural issues. Task-environmental depends on markets, customers, Competitors, Distribution \& dealers, Suppliers, Facilitators $\&$ marketing firms and Publics. For measuring Macro-environmental and Task-environmental, respondent will be asked through questionnaire in a seven-point Likert Scale, ranging from 1 "strongly Disagree" to 7 "Strongly Agree", which will be adapted from TP marketing group.

\section{Marketing Strategy Audit:}

Marketing strategy audit depends on business mission, marketing objectives and goals and marketing strategy. For measuring marketing strategy audit, respondent will be asked through questionnaire in a sevenpoint Likert Scale, ranging from 1 "strongly Disagree" to 7 "Strongly Agree", which will be adapted from TP marketing group.

\section{Marketing Organizational Audit:}

Marketing organizational audit depends on formal structure and functional efficiency. For measuring marketing organizational audit, respondent will be asked through questionnaire in a seven-point Likert Scale, ranging from 1 "strongly Disagree" to 7 "Strongly Agree", which will be adapted from TP marketing group.

\section{Marketing System Audit:}

Marketing system audit depends on marketing information system, marketing planning system and new product development system. For measuring marketing system audit, respondent will be asked through questionnaire in a seven-point Likert Scale, ranging from 1 "strongly Disagree" to 7 "Strongly Agree", which will be adapted from TP marketing group. 


\section{Marketing Productivity Audit:}

Marketing productivity audit depends on profitability analysis and cost effectiveness analysis. For measuring marketing productivity audit, respondent will be asked through questionnaire in a seven-point Likert Scale, ranging from 1 "strongly Disagree" to 7 "Strongly Agree", which will be adapted from TP marketing group.

\section{Marketing Function Audit:}

Marketing function audit depends on products, price, place (distribution), promotion and sales force. For measuring marketing function audit, respondent will be asked through questionnaire in a seven-point Likert Scale, ranging from 1 "strongly Disagree" to 7 "Strongly Agree", which will be adapted from TP marketing group.

\section{Organizational performance:}

Organization performance constructed by Sharabati (2010) and Karimi (2014) comprise three dimensions. For measuring organizational performance, respondent will be asked through questionnaire in a seven-point Likert Scale, ranging from 1 "strongly Disagree" to 7 "Strongly Agree", which will be adapted from TP marketing group.

\section{Data Analysis:}

The collection of data will be analyzed by the Statistical Package for the Social Sciences (SPSS) program. Additionally, SPSS 25 was used to obtain the descriptive analysis, factor analysis and reliability analysis. This study will apply the structure equation model (SEM) method to determine the significant influence between dependent variable, independent variables and meditating variables from collected data (Alavifar et al., 2012; Hair et al., 2016). The statistical program (Amos) Version 24.0 or SmartPLS 3.2 will be used to implement the structure equation model (SEM) to analyze the research hypotheses.

\section{Conclusion:}

Marketing audit is helpful for the success of a company which scrutinizes and compares the marketing plans of an organization with its actual marketing performance; detections strengths and weaknesses of an organization's product; advices an organization to adjust its marketing strategies with the changing marketing environment; helps an organization to control its marketing expenses and to update marketing strategies; and suggests to eradicate weaknesses of product. Through increasing marketing performance, it enhances the organization performance too. That is why, the study attempts to find out a conceptual model to explore the influence of marketing audit on organizational performance. Based on the developed model, the study will continue to discover the impact of marketing audit on performance of different types of business. Further studies can be done based on the different mediating and moderating factors between each dimension of marketing audit and organizational performance to find out the most important and most useable dimension of marketing audit. Applying this empirical study, organizations may generate new policies and strategies for improving performance in different types of organizations.

\section{REFERENCES}

Absar, M.M.N, B. Nimalathasan and M.M.A.K. Jilani, 2010. Impact of HR Practices on Organizational Performance in Bangladesh. International Journal of Business Insights and Transformation. 3(2): 15-19.

Achua, J.K. and T.T. Alabar, 2014. Imperatives of marketing internal auditing in Nigerian universities. Procedia-Social and Behavioral Sciences, 164: 32-40.

Akroush, M.N. and S.M. Al-Mohammad, 2010. The effect of marketing knowledge management on organizational performance: An empirical investigation of the telecommunications organizations in Jordan. International Journal of Emerging Markets, 5(1): 38-77.

Al Fahad, A., A.R. Al Mahmud, R. Miah and U.H. Islam, 2015. Marketing audit - a systematic and comprehensive marketing examination. International Journal of Science and Technology Research, 4(07): 215221.

Alavifar, A., M. Karimimalayer and M.K. Anuar, 2012. Structural equation modeling vs multiple regression. Engineering Science and Technology: An International Journal, 2(2): 326-329.

Alipour, M., A. Ghanbari and S. Moniri, 2011. The impact of marketing mix (4Ps) on marketing audit and performance in Iranian SMEs. International Journal of Humanities and Social Science, 1(2): 112-117.

Allaire, Y. and M. Firsirotu, 1990. Strategic plans as contracts. Long Range Planning, 23(1): 102-115.

American Marketing Association, 2013. https://www.ama.org, accessed on 25 November 2017

Armstrong, J.S. and T.S. Overton, 1977. Estimating Nonresponse Bias in Mail Surveys, Journal of Marketing Research, 14 (August), pp: 396-402. 
Arrow, K. J., 1985. Principals and agents: the structure of business. Harvard Business School Press. The U.S.A.

Baum, J. R., and S. Wally, 2003. Strategic decision speed and firm performance, Strategic Management Journal, 24: 1107-1129.

Beaver,1989. Drivers of market orientation and performance in service firms, Prentice Hall, England.

Bonoma, Thomas V. and B.H. Clark, 1988. Marketing Performance Assessment, Harvard Business School Press, Boston, Massachusetts, The U.S.A.

Bontis, N., 1998. Intellectual capital: an exploratory study that develops measures and models. Management decision, 36(2): 63-76.

Broberg, P., T. Umans and C. Gerlofstig, 2013. Balance between auditing and marketing: An explorative study. Journal of International Accounting, Auditing and Taxation, 22(1): 57-70.

Brownlie, D., 1993. The Marketing Audit: A Metrology of Explanation, Marketing Intelligence and Planning, 11 (1), 4-12.

Brownlie, D., 1996a. The Conduct of Marketing Audits: A Critical Review and Commentary, Industrial Marketing Management, 25(1): 11-22.

Brownlie, D., 1996b. Marketing Audits and Auditing: Diagnosis Through Intervention, Journal of Marketing Management, 12: 99-112.

Capella, L.M., and W.S. Sekely, 1978. The marketing audit: methods, problems and perspectives. Akron Business and Economic Review, 9(3): 37-41.

Chen-Ping, S., C. Wen-chih and M. Melton, 2010. The impact of intellectual capital on business performance in Taiwanese design industry, Journal of knowledge management practice, 11 (1): 1-25.

Chin, C.H., M.C. Lo and T. Ramayah, 2013. Market orientation and organizational performance-The moderating role of service quality. Sage Open, 3(4).

Clark, B.H., A.V. Abela and T. Ambler, 2006. An information processing model of marketing performance measurement. Journal of Marketing Theory and Practice, 14(3): 191-208.

Day, G., and L. Fahey, 1988. Valuing market strategies. The Journal of Marketing, pp: 45-57.

Day, G.S., and P. Nedungadi, 1994. Managerial representations of competitive advantage. The Journal of Marketing, pp: 31-44.

Dess, G. G., and D.W. Beard, 1984. Dimensions of organizational task environments', Administrative Science Quarterly, 29: 52-73.

Dhar, B.K., H.M. Rahouma, R. Masruki and M.M.N. Absar, 2017b. Impact of Islamic Human Resource Practices on Organizational Performance through Organizational Commitment in the Banking Sector of Bangladesh in proceeding of the 7th Islamic Economic System Conference, Sultanate of Oman.

Dhar, B.K., M. Mutalib and F. A. Sobhani, 2017a. Investigating the Impact of Human Resource Accounting Practice on Organizational Performance in proceeding of the International Islamic Social Economic Conference, Universiti Sains Islam Malaysia, Malaysia.

Diamantopoulos, A. and S. Hart, 1993. Linking market orientation and company performance: preliminary evidence on Kohli and Jaworski's framework. Journal of strategic marketing, 1(2): 93-121.

Drenth, B.V., M.E. Hulscher, J.C. Van der Wouden, HG. Mokkink, C. Van Weel and R.P. Grol, 1998. Relationship between practice organization and cardiovascular risk factor recording in general practice. $\mathrm{Br} \mathrm{J}$ Gen Pract, 48(428): 1054-1058.

Egeren, M.V. and S. O’Connor, 1998. Drivers of market orientation and performance in service firms. Journal of Services Marketing, 12(1): 39-58.

Hair Jr, J.F., G.T.M. Hult, C. Ringle and M. Sarstedt, 2016. A primer on partial least squares structural equation modeling (PLS-SEM). Sage Publications.

Han, J.K., N. Kim and R.K. Srivastava, 1998. Market orientation and organizational performance: is innovation a missing link?. The Journal of marketing, pp: 30-45.

Hasty, R., and J. Reardon, 1997. Retailing Management. McGraw Hill Companies, Inc.

Horngren, C.T., G. Foster and S.M. Datar, 2000. Cost Accounting: Managerial Emphasis, Prentice Hall, New Delhi.

Jennings, P., and G. Beaver, 1997. The performance and competitive advantage of small firms: a management perspective. International small business journal, 15(2): 63-75.

Jha, S.K., 2013. Marketing Audit-An Examination of Company's Marketing Position. Indian Journal of Research. 2(12).

Kaplan, R.S., and D.P. Norton, 2005. The balanced scorecard: measures that drive performance. Harvard Business School Publishing.

Karimi, J.M.N., 2014. Relationship between intellectual capital accounting and business performance in the pharmaceutical firms in Kenya (Doctoral dissertation, Jomo Kenyatta University of Agriculture and Technology). 
Katsikeas, C.S., N.A. Morgan, L.C. Leonidou and G.T.M. Hult, 2016. Assessing performance outcomes in marketing. American Marketing Association.

Khalique, M., A.N. Jamal, H. Abu and A. Adel, 2011. Relationship of Intellectual Capital with the Organizational Performance of Pharmaceutical Companies in Pakistan. Australian journal of Basic and Applied Sciences, 5(12): 1964-1969.

Khandwalla, P.N., 1977. The Design of Organizations, Harcourt, Brace, Jovanovich, New York.

Kohli, A.K., and B. Jaworski, 1990, Market Orientation: The Construct, Research Propositions, and Managerial Implications, Journal of Marketing, 54(2): 1-18.

Kotler, P. and R.E. Turner, 1979. Marketing management: analysis, planning and control. Englewood Cliffs, NJ: Prentice-Hall.

Kotler, P., 1967, Marketing Management: Analysis, Planning, and Control, Englewood Cliffs, N. J. Prentice-Hall, Inc.

Kotler, P., 1988, Marketing Management: Analysis, Planning, Implementation, and Control, 6th ed. Englewood Cliffs, N. J., Prentice Hall International.

Kotler, P., 1997, Marketing Management: Analysis, Planning, Implementation, and Control, 9th ed. Upper Saddle River, N. J., Prentice Hall

Kotler, P., Gregor, W. and W. Rodgers, 1977. The marketing audit comes of age. Sloan Management Review, 18(2): 25-43.

Kotler, P., P.T. Fitzroy and R.N. Shaw, 1980. Australian marketing management. Prentice-Hall of Australia.

Lai, K.H., and T.E. Cheng, 2005. Effects of quality management and marketing on organizational performance. Journal of Business research, 58(4): 446-456.

Lipnická, D., and J. Dado, 2013. Marketing audit and factors influencing its use in practice of companies (from an expert point of view). Journal of competitiveness, 5(4).

Loya, A., 2011. Marketing Audit- An Important Tool to Determine Strengths and Weaknesses of the Companies. International Journal of Multidisciplinary Management Studies, 1(2): 92-108.

McDonald, M., and J. Leppard, 1991. The marketing audit: translating marketing theory into practice. Butterworth-Heinemann.

Mohammadzadeh, M., S.M. Aarabi and J. Salamzadeh, 2013. Organizational performance, Marketing strategy, and Financial strategic.

Morgan, N.A., B.H. Clark and R. Gooner, 2002. Marketing productivity, marketing audits, and systems for marketing performance assessment: integrating multiple perspectives. Journal of Business Research, 55(5): 363375.

Mugenda, O.M. and A.G. Mugenda, 2003. Research Methods: Quantitative and qualitative approaches. Nairobi: ACTS Press.

Myers, M.T., and G.E. Myers, 1982. Managing by communication: An organizational approach. McGrawHill College.

Mylonakis, J., 2003. Functions and responsibilities of marketing auditors in measuring organizational performance, International Journal of Technology Management. McGraw Hill Publishers, London.

Narver, J.C., and S.F. Slater, 1990. The effect of a market orientation on business profitability. The Journal of marketing, pp: 20-35.

Odote, B.O and W.O. Robby, 2013. Marketing audit and performance: a case of parastatals, Lap Lambert Academic Publishing, Germany

Pelham, A.M., 2000. Market orientation and other potential influences on performance in small and medium-sized manufacturing firms. Journal of small business management, 38(1): 48.

Radulescu, V., and I. Cetina, 2012. Customer analysis, defining component of marketing audit. ProcediaSocial and Behavioral Sciences, 62: 308-312.

Rothe, J.T., M.G. Harvey and C.E. Jackson, 1997. The Marketing Audit: Five Decades Later, Journal of Marketing Theory and Practice, 5(3): 1-16.

Rudman, 1998. Intuitive Decision-Making, Communications of the ACM, Prentice Hall, England

Saif, N.M.A., 2015. How does Marketing Strategy Influence Firm Performance- Implementation of Marketing Strategy for Firm Success.

Sauter, V.L, 1999. Intuitive Decision-Making, Communications of the ACM, Prentice Hall, England.

Sharabati, A.A.A., S. Naji Jawad and N. Bontis, 2010. Intellectual capital and business performance in the pharmaceutical sector of Jordan. Management decision, 48(1): 105-131.

Sheth, J.N., and R.S. Sisodia, 2002. Marketing productivity: issues and analysis. Journal of Business research, 55(5): 349-362.

Shuchman, A., 1959. The marketing audit: its nature, purposes and problems, In Garden, A. N. and Bailey, E. R. (Ed.), Analyzing and improving marketing performance: marketing audits in Theory and practice, McGraw Hill Publishers, New York. 
Solod, M.E., 1996. Conducting a Marketing Audit: A Service Organization Illustration, Journal of Professional Services Industry, 14(2): 39-54.

Sutcliffe, J., 1975. The Marketing Audit. The PA Australian Management Series, Melbourne, Hutchinson of Australia.

Taghian, M., and R.N. Shaw, 1998. The Marketing Audit and Business Performance: A Review and Research Agenda. In Proceedings of the Australian and New Zealand Marketing Academy Conference, University of Otago, Dunedin/NZ, pp: 2557-2571.

Taghian, M., and R.N. Shaw, 2008. The marketing audit and organizational performance: an empirical profiling. Journal of Marketing Theory and Practice, 16(4): 341-350.

TP Marketing Group, Marketing strategy Audit Questionnaire. http://www.marketingaudit.co.uk/process.htm, accessed on 22 November 2017.

Trice, H.M., and J.M. Beyer, 1984. Studying organizational cultures through rites and ceremonials. Academy of management review, 9(4): 653-669.

Ullah, M., and H.M. Ahmad, 2017. The Impact of Internal Marketing on the Organizational Performance through Organizational Culture Mediation. Abasyn University Journal of Social Sciences, 10(1).

Wallace, 1980, 1987. Marketing Resource Realization, Southwestern Inc., London.

Wilson, A., 1982. Marketing Audit Checklist: A Guide to Effective Marketing Resource Realization, London, McGraw Hill.

Wilson, A., 1993. Marketing Audit Checklist: A Guide to Effective Marketing Resource Realization, 2nd Edition, London, McGraw Hill.

Wu, W.K., H.C. Chen and Y.X. Huang, 2015. Antecedents and consequences of marketing audits: Empirical evidence from Taiwanese firms. Asia Pacific Management Review, 20(3): 156-164.

Zahra, S.A., 1996. Technology Strategy and Financial Performance: Examine the Moderating Role of the Firm's Competitive Environment, Journal Business Venturing, 11: 189-219. 